\title{
GROWTH-CLIMATE RELATIONSHIPS OF PINUS STROBUS IN THE FLOODWAY VERSUS TERRACE FOREST ALONG THE BANKS OF THE RED CEDAR RIVER, MICHIGAN
}

\author{
SOPHAN CHHIN ${ }^{1}$, KATHERINE CHUMACK ${ }^{1}$, TRAVIS DAHL ${ }^{2,3}$, ERIC T. DAVID ${ }^{1}$, PHILLIP KURZEJA ${ }^{4}$, \\ MATTHEW MAGRUDER ${ }^{1}$, and FRANK W. TELEWSKI ${ }^{4,5}$ * \\ ${ }^{1}$ Department of Forestry, Michigan State University, Natural Resources Building, 480 Wilson Road, East Lansing, MI \\ 48824-1222, USA \\ ${ }^{2}$ Department of Geology, Michigan State University, Natural Science Building, 288 Farm Lane, Room 206, East Lansing, \\ MI 48824, USA \\ ${ }^{3}$ U.S. Army Corps of Engineers, Great Lakes Hydraulics \& Hydrology, 477 Michigan Ave, Detroit, MI 48226, USA \\ ${ }^{4}$ Department of Plant Biology, Michigan State University, Plant Biology Building, 612 Wilson Road, Room 166, East \\ Lansing, MI 48824, USA \\ ${ }^{5}$ W.J. Beal Botanical Garden and Campus Arboretum, Michigan State University, Olds Hall, 408 West Circle Drive, \\ Room 412, East Lansing, MI 48824, USA
}

\begin{abstract}
We examined the effects of climate (i.e. temperature, precipitation, moisture index, river discharge) on the radial growth of eastern white pine (Pinus strobus) in two contrasting microhabitats (floodway versus terrace) in relation to an elevational and moisture gradient along the banks of the Red Cedar River, Michigan. We hypothesized that trees growing on the terrace sites would have a greater sensitivity to climatic factors than trees growing in the floodway. Increment cores were sampled and crossdated from dominant and co-dominant trees in the floodway and terrace sites and standardized growth chronologies were developed. Mean sensitivity, standard deviation, percentage of absent rings, and intertree correlation were generally greater for eastern white pine on the terrace compared to the floodway forests. Dendroclimatic relationships were examined with bootstrapped correlation analysis, which indicated that radial growth of eastern white pine in both floodway and terrace sites was negatively associated with summer temperature (i.e. June and July) of the current growing season. Radial growth in both floodway and terrace sites were positively related to current May precipitation, moisture index, and river discharge. Dendroclimatic response of eastern white pine in floodway and terrace sites differed in that the effect of summer moisture stress was more persistent in the terrace sites into later summer (i.e. current July ) whereas floodway sites showed a negative response to prior-year May precipitation and moisture index. Although precipitation and hydrological conditions of the river were generally favorable during the summer months, which appeared to have promoted soil moisture recharge, flooding in early winter (i.e. prior November) had a negative impact on growth in both microhabitats. The effect of winter river discharge was significantly negative in January (t) in the floodway sites compared to the terrace sites.
\end{abstract}

Keywords: climate, tree rings, dendrochronology, Pinus strobus, river hydrology, ecology.

\section{INTRODUCTION}

Eastern white pine (Pinus strobus L.) is a dominant tree in conifer and mixed conifer forests of eastern North America and is a major timber species that was harvested extensively in the late

*Corresponding author: telewski@msu.edu 19th and early 20th Centuries in the Great Lakes Region (Wendel and Smith 1990; Telewski 1998; Dickmann and Leefers 2003). The species has also shown great potential in dendroclimatic and dendroecological studies (Graumlich 1993; Abrams et al. 2000; Black and Abrams 2005; Kilgore and Telewski 2006; Mácová 2008; St. George et al. 2008; Kipfmueller et al. 2010). 
Dendrochronological studies have also been conducted to better understand growth responses to silvicultural treatments (Clinton et al. 1997; Orwig and Abrams 1999; Bebber et al. 2004) and forest health (Ostry et al. 2010). Pinus strobus is usually found on well-drained sandy soils of low to medium site quality as it is able to out-compete hardwood species under these conditions (Wendel and Smith 1990). However, it is also found growing in low-lying wet and boggy areas (Clausen 1957; Horton and Brown 1960; Orwig and Abrams 1999).

Beginning in the late 19th Century, efforts to experiment and encourage replanting of forest trees species including Pinus strobus were initiated in the state of Michigan, resulting in a number of test plantations (Telewski 1998, Kilgore and Telewski 2006). One plantation of Pinus strobus, the Beal Pinetum, was established in 1896 on 0.89 hectares of floodplain along the Red Cedar River on the campus of Michigan State University (Telewski 1998). The nature and age of the plantation provides an interesting model to test the climatic growth response of Pinus strobus growing in a central Michigan floodplain.

Trees growing in areas where water is less limiting for growth tend to form relatively uniform annual growth rings, referred to as being "complacent" (Fritts 1976). However, a few studies have reported tree species that respond to climatic variability even when growing in wet to saturated soils (Stahle et al. 1991; Orwig and Abrams 1999; Keim et al. 2012). The Beal Pinetum was planted along the banks of the Red Cedar River providing two microhabitats; one frequently flooded during the winter and spring, and the other slightly higher $(2.5 \mathrm{~m})$ terrace rarely inundated by floodwaters.

Differences in the hydraulic environment within a forested stand are known to influence tree growth rates as well as species composition (Anderson and Mitsch 2008; Rodriguez-Gonzalez et al. 2010). These differences in growth rates can be attributed, in part, to the relationship between the surface elevation and the water table level (Copenheaver et al. 2007). Keeping an optimal depth to the water table is important in terms of tree growth as it regulates the access a tree has to sufficient amounts of water but not so much that the roots become anoxic (Whitney 1990). Therefore, the growth of a tree can be influenced by the depth of the water table. The depth of the water table can be regulated by the surface elevation. Therefore, two trees that are growing relatively close to each other, but are growing at different elevations, say on top of and below a terrace, can exhibit differences in their growth as a result of their distance from the groundwater in the vertical soil column (Foster and Brooks 2001). The water table elevation can also be influenced by a change in flow of a nearby river (Ford and Brooks 2002).

The objective of this study is to examine the effects of climate (temperature, precipitation, moisture index, stream flow) on radial growth of eastern white pine in relation to an elevational and moisture gradient in terms of proximity to a river. The following hypotheses were tested: (1) trees growing on the terrace will have a greater sensitivity to precipitation than trees growing in the floodway, and (2) all trees growing in the Beal Pinetum will have a lower sensitivity to climate than other Pinus strobus chronologies developed from stands in Michigan more distant from alluvial areas.

\section{METHODS}

\section{Study Site}

The study was conducted in a 0.89 hectare eastern white pine plantation that was initiated by Professor William James Beal (Michigan State University) in 1896 and is commonly referred to as the Beal Pinetum (Figure 1; Telewski 1998). According to the original plan for the Beal Pinetum, white pine trees were established on a $3.05 \mathrm{~m} \times 3.66 \mathrm{~m}$ grid on land cleared of original vegetation and cultivated. The plantation is naturally subdivided into a terrace and floodway. The terrace is $2.5 \mathrm{~m}$ higher in elevation than the floodway (Michigan State University 2012).

Planted as a pure stand of white pine, currently the Beal Pinetum also contains a mixture of box elder (Acer negundo L.), red maple (Acer rubrum L.), silver maple (Acer saccharinum L.), bitternut hickory (Carya cordiformis (Wangenh.) K. Koch), mulberry (Morus rubra L.), black cherry (Prunus serotina Ehrh.), basswood (Tilia 

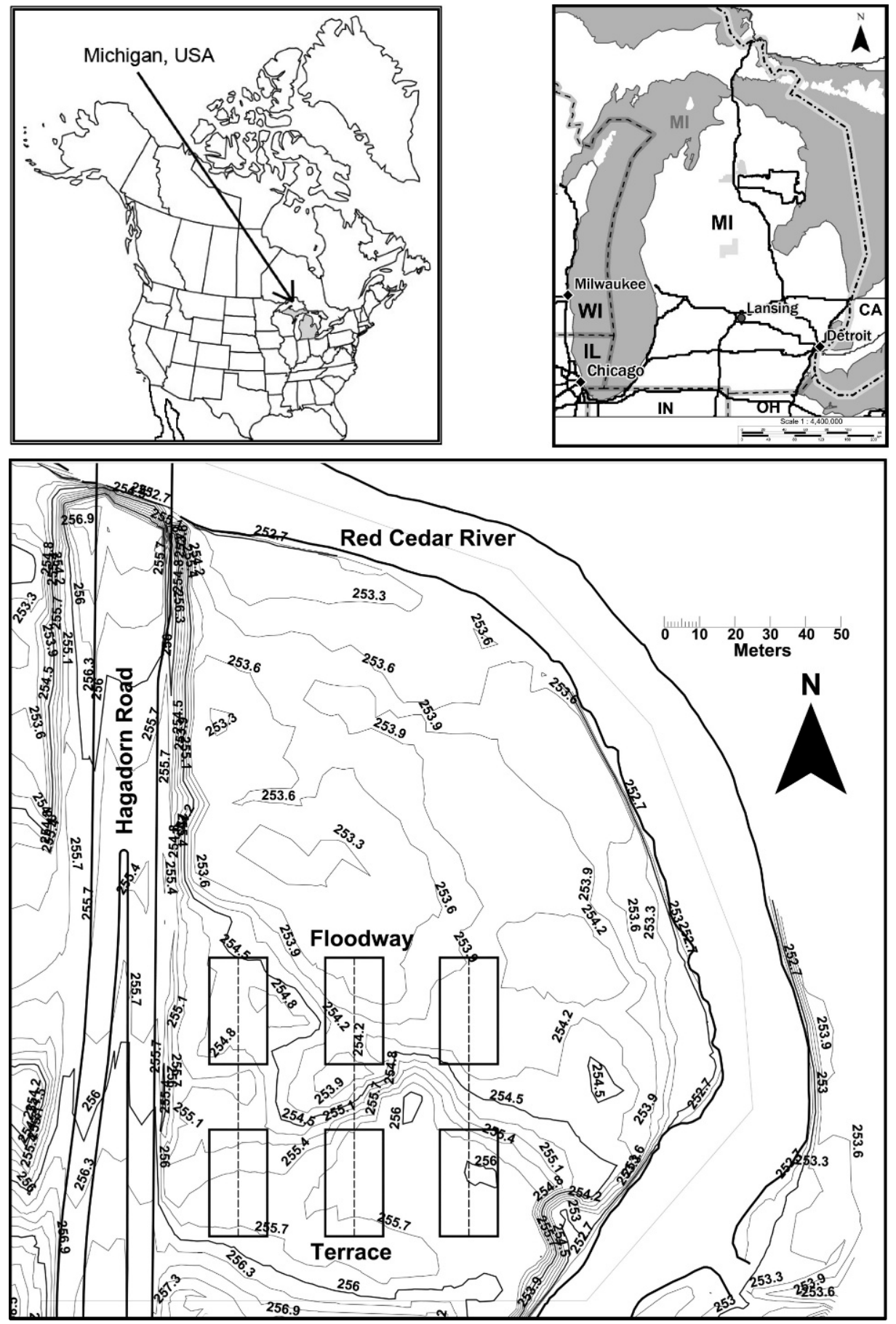

Figure 1. The location of Michigan positioned within North America (upper left). Regional context of study area (upper right) in Lansing, Michigan (MI) and neighboring states ( $\mathrm{IL}=$ Illinois, $\mathrm{IN}=$ Indiana, $\mathrm{OH}=$ Ohio, WI $=$ Wisconsin $)$ and countries $(\mathrm{CA}=$ Canada). Enlarged map of study site and field sampling design (bottom) within the Beal Pinetum along the banks of the Red Cedar River, East Lansing, MI. Three transects (dashed lines) were extended from the floodway to the terrace forest plots (rectangles) along the banks of the Red Cedar River. Topographic contours are marked with elevation in meters. 
americana L.), and American elm (Ulmus americana L.), which have established since the original planting. Presently, because of shady understory conditions and lack of major disturbances in this stand, sugar maple (Acer saccharum Marsh.) is becoming a prominent competitor tree species within the stand of white pine.

According to the nearest meteorological station (East Lansing 4S, Station ID: MI2395) and for the reference period of 1971-2000, the mean annual temperature is $8.3^{\circ} \mathrm{C}$ with the warmest mean monthly temperatures in July $\left(21.5^{\circ} \mathrm{C}\right)$ and the coldest mean monthly temperatures occurring in January $\left(-5.8^{\circ} \mathrm{C}\right)$ (Figure 2a). Total annual precipitation is $782 \mathrm{~mm}$ with most precipitation occurring in the months of August $(86.3 \mathrm{~mm})$ and September $(86.4 \mathrm{~mm})$ (Figure 2a). For the hydrological station located at the Red Cedar River at East Lansing, Michigan (Station ID: USGS 04112500) and for the reference period of 1971-2000, river discharge peaks in the spring months of March $\left(15.5 \mathrm{~m}^{3} / \mathrm{s}\right)$ and April $\left(14.4 \mathrm{~m}^{3} / \mathrm{s}\right)$ and drops to its lowest rate in late summer in August $\left(2.1 \mathrm{~m}^{3} / \mathrm{s}\right)$ (Figure 2b). Characteristically, these soils are well-drained, sandy loam soils, with a depth of more than 2 meters to the water table. The prominent soil type of the area is an urban land Boyer-Spinks complex (U.S. Natural Resources Conservation Service 2012).

\section{Field Sampling}

Three 76.2-m-long belt transects, running north to south through the plantation were established (Figure 1). The transects were oriented along a moisture and slight elevational gradient along the banks of the Red Cedar River, from the wetter, lower region (i.e. floodway) with close proximity to the Red Cedar River towards a drier, slightly higher region (i.e. terrace). Each belt transect was $15.2 \mathrm{~m}$ wide and was placed within at least a $15.2 \mathrm{~m}$ buffer zone from the plantation stand edge. Belt transects were spaced $15.2 \mathrm{~m}$ from each other and centered on the edge of the terrace. The transects were divided into two regions: the first $30.5 \mathrm{~m}$ of each belt transect is hereafter referred to as the floodway forest portion of the transect and the last $30.5 \mathrm{~m}$ of the transect is the
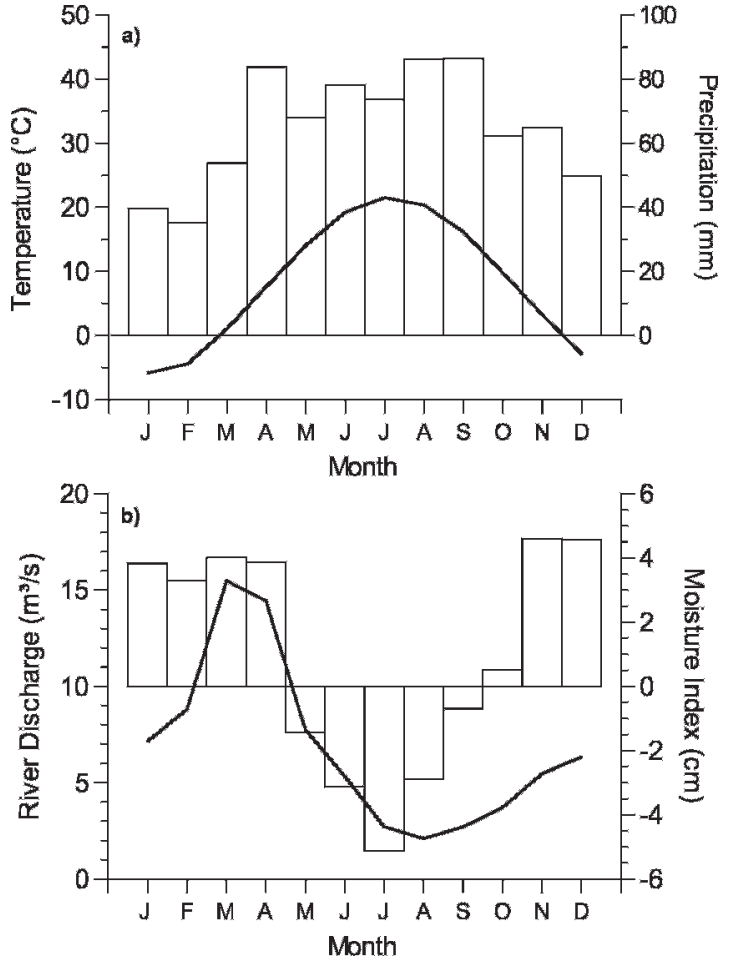

Figure 2. Climate diagram for the East Lansing climate station and hydrological station for the reference period of 1971-2000 for (a) mean monthly temperature (solid line) and total monthly precipitation (open bars), and (b) river discharge (solid line) and Climate Moisture Index (open bars), respectively.

terrace forest portion. When available, the 8 largest dominant and co-dominant trees in each of the 6 belt transect regions were cored at breast height $(1.3 \mathrm{~m})$. Two cores, one on the north-facing side and one on the south facing side, were sampled from each tree using an increment borer. In the case of a leaning tree, the two cores were taken on opposing sides of the tree, i.e. perpendicular to the lean. A diameter measurement was taken at breast height (DBH).

Supplemental stand measurements were also recorded for the purpose of obtaining a better understanding of present day stand density and tree species composition. At the midpoint of each transect region, a 7.6-m radius circular plot was established. The DBH and species identity was recorded for each tree in the plots.

In terms of the stand-level data, DBH of eastern white pine and interspecific competitors was expressed as stand basal area on a per-hectare 
basis. In addition, DBH was inputted into allometric biomass equations to provide an estimate of total aboveground biomass $(\mathrm{kg})$ expressed on a per-hectare basis (Jenkins et al. 2003). Two-sample t-tests (pooled variance) were conducted to compare the stand growth parameters of floodway versus terrace forest for each species grouping (SYSTAT 2006). Two-sample ttests (pooled variance) were also conducted to compare the stand growth parameters of eastern white pine versus competitors for either floodway or terrace forests. Percentage-based species composition data were transformed using an arcsin transformation and then compared between floodway and terrace forests using two-sample t-tests (pooled variance).

\section{Crossdating}

All tree cores were mounted, sanded up to 600 grit, and crossdated using standard dendrochronological techniques (Stokes and Smiley 1996). The cores were visually crossdated using a mixture of the skeleton plotting (Stokes and Smiley 1996) and the list method (Yamaguchi 1991) to identify any missing and/or false double rings. After successful completion of the visual crossdating, all cores were digitally scanned at an optical resolution of $1200 \mathrm{dpi}$. Annual ring widths were measured with an image analysis program (CooRecorder and Cdendro Ver. 7.3; Sweden). Difficult sections of some increment cores containing extremely narrow rings were measured with a stage micrometer coupled with a stereo microscope to an accuracy of $0.001 \mathrm{~mm}$ (Velmex: Bloomfield, New York). Statistical crossdating, through the program COFECHA (GrissinoMayer 2001), was utilized following the visual crossdating procedure to check for any tree-ring anomalies (i.e. missing rings and/or false rings).

\section{Data Analysis}

Using the program ARSTAN (Ver. 6.05P, Holmes 1992), the ring-width measurements were detrended using a 50-year cubic smoothing spline (Cook and Peters 1981). A 50-year cubic smoothing spline was chosen to preserve the high- frequency variation and year-to-year changes in growth. A 50-year spline preserves $99 \%$ of the variation in each ring-width series at a wavelength of about 15 years. Consequently, common trends (1-15 years) between trees are conserved. Each measured series was thus converted into dimensionless ring-width indices through standardization (i.e. dividing the observed values by the predicted values). The purpose of standardization was to amplify the climatic signal (high-frequency or interannual variation) while removing the lowfrequency or long-term variation frequently associated with non-climatic factors (e.g. age-related trend) (Fritts 1976). The Beal Pinetum is a closed canopy stand and smoothing splines remove competitive effects from the tree-ring data. Use of a shorter, more flexible spline increases the risk of removing climatic signals from our chronologies. The standardized ring-width series were combined and averaged together into a site chronology using a biweight robust mean of the ring-width series pooled for the floodway forests and the terrace forests. The expressed population signal (EPS) was determined, and it represents the chronology signal as a fraction of the total chronology variance, i.e. it quantifies the degree to which a particular sample chronology portrays a hypothetically perfect chronology (Briffa and Jones 1990). An expressed population signal (EPS) of at least 0.85 indicates robust chronology signal strength (Briffa and Jones 1990). EPS and correlation analysis was conducted over a common interval analysis period of 1919-2011 to assess the degree of growth synchrony of trees sampled within floodway or terrace sites. Chronology descriptors were compared between floodway and terrace forests using a two-sample t-test (pooled variance, Table 2).

Minimum, mean and maximum monthly temperature, and total monthly precipitation were obtained from nearby meteorological stations (East Lansing 4S, Station ID: MI2,395; East Lansing Experiment Farm, Station ID: MI 2,393) for the period of 1949-2010. A monthly climatic moisture index was also calculated by subtracting values of potential evapotranspiration (PET) from precipitation (Hogg 1997). The moisture index combines the effect of both 
precipitation and minimum and maximum monthly temperature on moisture regimes (Hogg 1997). Monthly hydrological discharge data were also obtained from the Red Cedar River at East Lansing, Michigan (Station ID: USGS 04112500) (USGS 2011). Dendroclimatic analysis was then performed using the program DendroClim 2002 (Biondi and Waikul 2004) to compare standardized chronologies against the monthly climatic variables. Although chronologies extend back in time as far as 1901 for the terrace forests, climatic data for the area were only available from the U.S. National Climate Data Center from 1949 to 2011. Thus, dendroclimatic analysis was run for the period of time of overlapping radial growth and climatic data: i.e. from 1950 to 2010 for April of the preceding year to October of the current year of growth. DendroClim conducted a bootstrapped correlation analysis and generated correlation coefficients between growth index chronology and each climatic variable (Biondi and Waikul 2004). Significant correlations are determined through 1,000 bootstrapped samples, which are drawn at random with replacement from each year in the data set (Biondi and Waikul 2004). Statistical significance is determined from the correlation coefficients from the original data set that fall outside of the $95 \%$ range of 1,000 bootstrapped data sets (Biondi and Waikul 2004).

\section{RESULTS}

\section{General Stand Characteristics}

In the floodway forests, species composition (and percentage relative to total number of trees in the region) consisted of $P$. strobus L. (57.1\%), A. saccharum Marsh. (38.1\%), C. cordiformus (Wangenh.) K. Koch (2.4\%), and Ulmus americana L. $(2.4 \%)$. In the terrace forests, species composition (and percentage) consisted of $P$. strobus L. (58.5\%), A. saccharum Marsh. (34.1\%), Acer rubrum L. (2.4\%), Prunus serotina Ehrh. (2.4\%), and Morus rubra L. (2.4\%). Composition of each of these species was not significantly different between floodway and terrace forests (all $\mathrm{p}>$ 0.05). DBH, basal area, and biomass of either eastern white pine or other interspecific competitors tended to be greater in the terrace than the floodway forests but the differences were not statistically significant (Table 1). For both the floodway or terrace forests, eastern white pine had significantly higher $\mathrm{DBH}$, basal area, and biomass than interspecific competitors (all $\mathrm{p}<0.05$ ).

\section{General Chronology Characteristics}

Mean sensitivity (Fritts 1976; GrissinoMayer 2001), standard deviation, and percentage of absent rings were generally greater for eastern white pine in the terrace compared to the floodway sites, although the difference was only significant for mean sensitivity ( $p=0.037$ ) (Table 2). An EPS value of 0.85 was reached with a slightly lower sample size (12 trees) for the terrace sites compared to the floodway sites (14 trees). Over the common time interval (1919-2011), eastern white pine trees in the terrace sites had a greater EPS value, and slightly higher inter-core, intertree, and intra-tree correlation compared to the floodway sites, although these minor differences were not statistically significant (all $\mathrm{p}>0.05$, Table 2).

Table 1. Average stand level productivity parameters of (a) eastern white pine, (b) interspecific competitors, and (c) all species combined for the floodway and terrace forests. The standard error of the mean of each stand growth parameter is enclosed in parentheses. For each species and stand growth parameter, comparisons of floodway versus terrace forest with different lowercase letters are statistically significant $(\mathrm{p}<0.05)$. For either floodway or terrace forests and for each stand growth parameter, comparisons of eastern white pine versus competitors with different uppercase letters are statistically significant ( $p<0.05$ ).

\begin{tabular}{lrr}
\hline $\begin{array}{c}\text { Species and Stand Growth } \\
\text { Parameter }\end{array}$ & \multicolumn{1}{c}{ Floodway } & \multicolumn{1}{c}{ Terrace } \\
\hline a) Eastern white pine & & \\
DBH $(\mathrm{cm})$ & $48.0(2.3) \mathrm{a}, \mathrm{B}$ & $48.7(2.6) \mathrm{a}, \mathrm{B}$ \\
Basal area $\left(\mathrm{m}^{2} / \mathrm{ha}\right)$ & $75.7(6.7) \mathrm{a}, \mathrm{B}$ & $83.3(7.9) \mathrm{a}, \mathrm{B}$ \\
Biomass (metric tons/ha) & $423.5(31.7) \mathrm{a}, \mathrm{B}$ & $461.4(49.9) \mathrm{a}, \mathrm{B}$ \\
b) Interspecific competitors & & \\
DBH (cm) & $18.5(0.8) \mathrm{a}, \mathrm{A}$ & $21.3(1.5) \mathrm{a}, \mathrm{A}$ \\
Basal area (m $2 /$ ha) & $9.5(3.6) \mathrm{a}, \mathrm{A}$ & $13.0(5.1) \mathrm{a}, \mathrm{A}$ \\
Biomass (metric tons/ha) & $58.7(22.4) \mathrm{a}, \mathrm{A}$ & $89.3(43.3) \mathrm{a}, \mathrm{A}$ \\
c) All species & & \\
DBH (cm) & $36.5(3.5) \mathrm{a}$ & $37.6(2.0) \mathrm{a}$ \\
Basal area (m $\left.{ }^{2} / \mathrm{ha}\right)$ & $85.2(9.4) \mathrm{a}$ & $96.3(11.6) \mathrm{a}$ \\
Biomass (metric tons/ha) & $482.1(47.1) \mathrm{a}$ & $550.7(84.2) \mathrm{a}$ \\
\hline
\end{tabular}


Table 2. General statistics of the standard chronology of eastern white pine from the floodway and terrace forests. For each chronology statistic, comparisons of floodway versus terrace forest with different lowercase letters are statistically significant $(p<0.05)$. Note, only the mean sensitivity is significantly different.

\begin{tabular}{lcc}
\hline \multicolumn{1}{c}{$\begin{array}{c}\text { Chronology } \\
\text { Characteristics }\end{array}$} & Floodway & Terrace \\
\hline a) Chronology Length & $1900-2011$ & $1901-2011$ \\
No. of trees (radii) & $22(42)$ & $25(50)$ \\
Mean ring width (mm) & $1.76 \mathrm{a}$ & $1.80 \mathrm{a}$ \\
Mean sensitivity & $0.13 \mathrm{a}$ & $0.18 \mathrm{~b}$ \\
Standard deviation & $0.18 \mathrm{a}$ & $0.23 \mathrm{a}$ \\
Absent rings (\%) & $0.024 \mathrm{a}$ & $0.203 \mathrm{a}$ \\
Expressed population & $1907-2011(14)$ & $1904-2011(12)$ \\
$\quad$ signal (EPS) & & \\
b) Common Interval & $1919-2011$ & $1919-2011$ \\
$\quad$ Analysis & & \\
No. of trees (radii) & $16(29)$ & $21(37)$ \\
Expressed population & $0.87 \mathrm{a}$ & $0.91 \mathrm{a}$ \\
$\quad$ signal (EPS) & & \\
Intercore correlation & $0.29 \mathrm{a}$ & $0.33 \mathrm{a}$ \\
Intertree correlation & $0.29 \mathrm{a}$ & $0.33 \mathrm{a}$ \\
Intratree correlation & $0.52 \mathrm{a}$ & $0.54 \mathrm{a}$ \\
\hline
\end{tabular}

${ }^{1}$ The time period and the number of trees in parentheses to reach an EPS level of 0.85 .

Notable periods of below-average growth in the terrace forests during 1961-1967, 1983-1999, and 2005-2007, were not as reduced in the floodway radial growth chronology (Figure 3). The year of lowest growth in both floodway and terrace sites was 1988 .

\section{Growth-Climate Relationships}

According to the bootstrapped correlation analysis, mean temperature in June and July of the current year $(\mathrm{t})$ for both eastern white pine in the floodway forests $(r=-0.31, r=-0.29$, respectively) and terrace forests $(r=-0.30, r=-0.33$, respectively) were negatively associated with tree growth (Figure 4a).

Growth was positively correlated with total monthly precipitation in May, with a slightly stronger response in the floodway forests $(\mathrm{r}=$ $0.39)$ versus the terrace forests $(r=0.28)$ (Figure 4b). The floodway forests were also positively correlated with precipitation in May of the prior year $(\mathrm{t}-1)(\mathrm{r}=0.30)$ and negatively

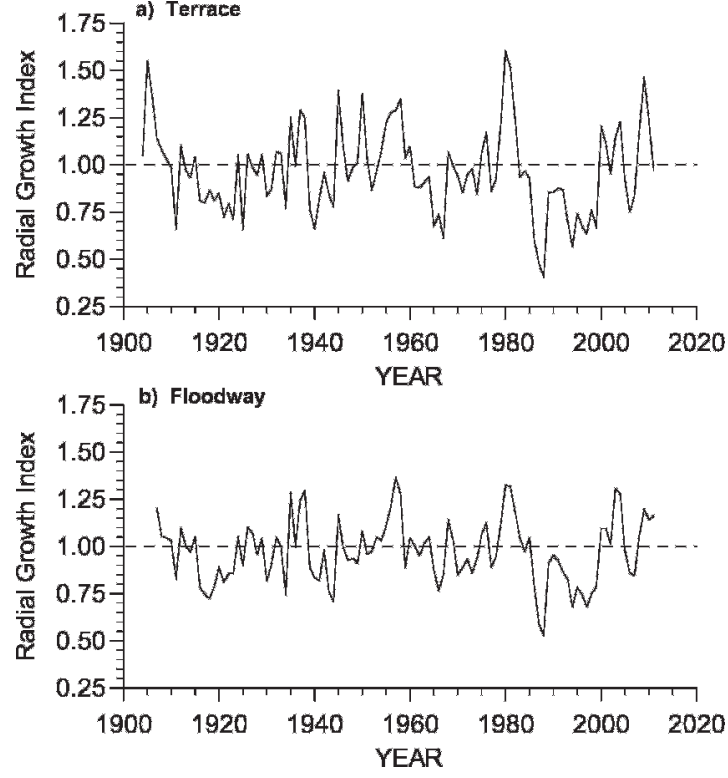

Figure 3. The standardized chronology of eastern white pine in terrace (a) and floodway (b) sites for their respective chronology time periods when the expressed population signal was greater than 0.85 .

related to precipitation in January $(\mathrm{r}=-0.21)$. Growth of trees in the floodway forests showed a similar response to the moisture index as it did with total monthly precipitation (Figure 4c) in the months of May (t-1), January (t), and May (t). For the terrace forests, growth was positively correlated with May $(r=0.26)$ and July $(r=0.31)$ moisture index of the current year.

Growth was negatively associated with river discharge in November (t-1) and positively related to river discharge in May $(\mathrm{t})$ for both the floodway sites $(\mathrm{r}=-0.24, \mathrm{r}=0.29$, respectively) and the terrace sites $(r=-0.24, r=0.27$, respectively) (Figure 4d). In addition, growth in the floodway forests was negatively correlated with river discharge in January $(r=-0.20)$.

\section{DISCUSSION}

\section{General Stand Characteristics}

Both the floodway and terrace sites were dominated by eastern white pine with a strong component of sugar maple growing in the understory and some minor components of other 

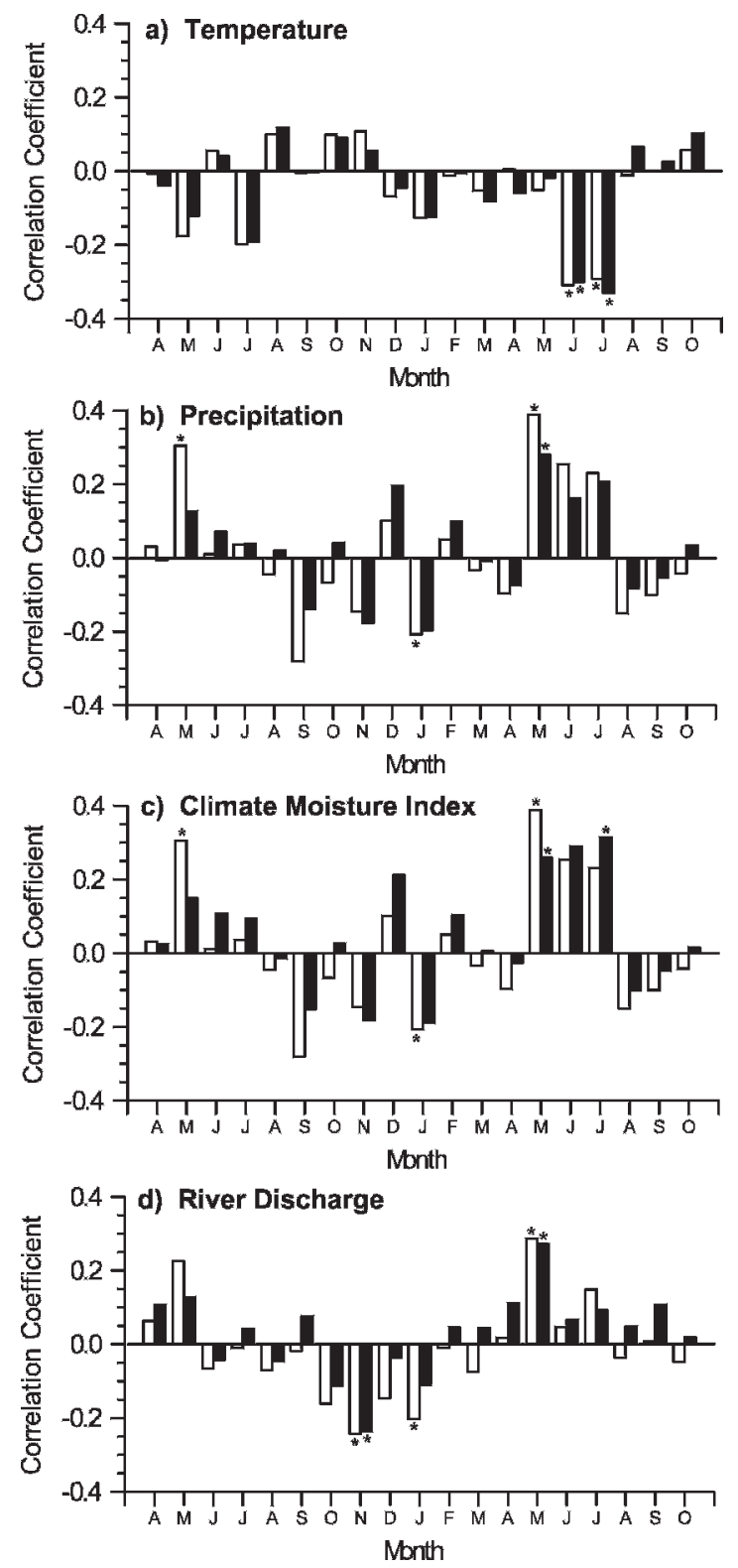

Figure 4. Pearson correlation coefficients between the standard chronology of eastern white pine from the floodway (open bars) and terrace (filled bars) forests within the Beal Pinetum and (a) mean temperature, (b) total precipitation, (c) climate moisture index, and (d) river discharge for the period of 1949-2010. Monthly climate variables denoted with an asterisk were statistically significant $(\mathrm{p}<0.05)$ according to bootstrapped correlation analysis.

deciduous species. The lack of significant differences between the two sites with respect to the species composition and average stand-level productivity parameters indicated that any site- specific competition from the deciduous subcanopy species minimally affects the growth pattern of the mature eastern white pines when comparing the two sites dendrochronologically.

\section{Chronology Sensitivity}

The results indicated that the standardized growth chronology of eastern white pine from the terrace sites was generally more sensitive, indicated by the higher mean sensitivity, standard deviation, and percentage of absent rings. The stronger role of external climatic forcing on eastern white pine growing in the terrace forests compared to the floodway sites was also underscored by the larger EPS value and intertree correlation. Furthermore, periods of below-average growth and the degree of growth suppression was much greater in eastern white pine trees sampled in the terrace versus the floodway forests. The generally more complacent growth pattern of eastern white pine from the floodway forest was expected given the closer proximity to the Red Cedar River where the depth to the ground water table would be expected to be much less than the trees sampled higher up the banks in the terrace forest of the Red Cedar River. The year of most pronounced growth reduction in both floodway and terrace sites was in 1988 which is recognized as a key drought year in the U.S. Midwest (Leavitt 2007) and other ecological regions of North America.

The mean sensitivity of white pine sampled across four sites in the upper Great Lakes region in the Upper Peninsula of Michigan and northern Wisconsin averaged 0.18 (range 0.15-0.20) (Graumlich 1993), comparable to the terrace forests reported in the current study. Furthermore, Kilgore and Telewski (2004) also reported a mean sensitivity of 0.18 for white pine in the northern region of the Lower Peninsula growing on deep glacial sand. This value for mean sensitivity is similar to the terrace sites of the current study. Kipfmueller et al. (2010) reported a higher mean sensitivity of white pine at two sites $(0.21$ and 0.23$)$ in northern Minnesota, which is likely attributable to the more xeric site conditions comprised of thin soils overlying glacial till. 


\section{White Pine Growth Response to Climate}

The bootstrapped correlation analysis indicated that growth of eastern white pine in both the floodway and terrace sites was affected by high temperature stress in the June and July of the current growing season. High summer temperatures generally lead to increased rates of respiration, which can lead to reduced net photosynthetic gain (Kozlowski et al. 1991; Dougherty et al. 1994). High temperatures can also induce moisture stress by increasing rates of potential evapotranspiration and this linkage is further supported by the positive correlation to the July moisture index for the terrace region. Similarly, Kipfmueller et al. (2010) also observed that white pine in northern Minnesota had negative correlations and response function coefficients with current summer maximum and minimum temperature in the month of June; furthermore trees were also stressed by high maximum temperature in early spring of the current year (i.e. March).

In contrast, an eastern white pine chronology developed for a site in the northern portion of the Lower Peninsula of Michigan showed a significant positive correlation to mean April temperature (Kilgore and Telewski 2004). Furthermore, Graumlich (1993) found that radial growth of pine species (i.e. white pine and red pine) sampled at more northerly latitudes in the upper Great Lakes region in the Upper Peninsula of Michigan and northern Wisconsin also responded favorably to April temperature. This response to early spring temperature was not observed in the current study, likely because the more southerly location of the current study allows for a comparatively earlier start to the growing season.

Radial growth of eastern white pine was positively related with May precipitation and moisture index in both the current year and the prior year (t-1) in the floodway sites and only for May of the current year for terrace site trees. A possible ecophysiological explanation for this is that early summer is generally considered the most active period of crown and foliage growth in conifers (Gower et al. 1995). Increased crown and foliage growth in one year may lead to increased carbohydrate reserves resulting in increased tree growth in the following growing season as well
(Kozlowski et al. 1991). The results support the idea that good crown and foliage growth early in the growing season translates into more photosynthate available for diameter growth in the current year and possibly the following year. The results also indicated that the moisture stress still impacted growth later in the summer (i.e. July (t)) for eastern white pine growing in the terrace versus floodway sites. This result was expected given the further distance of the terrace forests from the Red Cedar River and thus the greater depth to the water table. Kipfmueller et al. (2010) also found that ring width in white pine in northern Minnesota was positively correlated with summer precipitation and moisture index (Palmer Drought Severity Index) in the current year.

Cambial growth in Pinus strobus growing in Michigan ceases by September or October, whereas root and ectomycorrhizae growth continue into November during an active period for phosphorus absorption (Lussenhop and Fogel 1999). The highest period for phosphorus absorption is in May. Flooding will increase anoxic soil conditions (Kozlowski 1997). The negative growth associated with November (t-1) and January (t) river discharge may be associated with a waterlogged soil, anoxic-induced suppression of late growing season root growth, respiration, and possibly a reduction in phosphorus absorption. The anoxic conditions during winter months may also be responsible for mortality of fine roots and mycorrhizae. This would require an investment of carbon to restore root function in the spring while also reducing water absorption for growth. A required investment of carbon to restore root function will affect both the floodway and terrace in November of the prior year but was more persistent in the floodway because growth continued to respond negatively to river discharge, precipitation, and moisture index in January of the current year. On the other hand, flooding during May occurs at a time of higher moisture stress (Figure 2b) and active transpiration. Soil saturation levels may not remain high for a prolonged period of time and flooding may actually recharge soil moisture content to the benefit of tree growth. The conditioning role of climate (i.e. precipitation, moisture index, river 
discharge) in May on growth is also likely a result of May being a turning point in the decrease of the climatic norms for river discharge and moisture index compared to the relatively higher values in the preceding April (Figure 2b). Growth of eastern white pine is likely attuned to the variability of climatic conditions during this seasonal transition period.

In conclusion, radial growth patterns of eastern white pine in the floodway region were generally more complacent than in the terrace sites. Nonetheless, significant dendroclimatic relationships were observed in both microhabitats. Growth in both microhabitats responded negatively to summer temperature and positively to summer precipitation although the effect of summer moisture stress was more persistent in the terrace sites. Although precipitation and hydrological impacts of the river were generally favorable for tree growth during the summer months, which appeared to have promoted soil moisture recharge, higher river discharge in early winter had a negative impact on growth in both microhabitats. The effect of higher river discharge and associated increased potential for flooding in winter was more persistent in the floodway sites compared to the terrace sites.

\section{ACKNOWLEDGMENTS}

We thank D.M. Monks for his assistance in the field data collection and sample measurement, J. Wilson for providing a copy of the Beal Pinetum topographic map, and Michigan State University Campus Natural Areas Committee for providing permission to sample the Beal Pinetum. We thank the Associate Editor (G. Wiles) and two anonymous reviewers for their comments on a prior version of the manuscript.

\section{REFERENCES CITED}

Abrams, M. D., S. van de Gevel, R. C. Dodson, and C. A. Copenheaver, 2000. The dendroecology and climatic impacts for old-growth white pine and hemlock on the extreme slopes of the Berkshire Hills, Massachusetts, U.S.A. Canadian Journal of Botany 78:851-861.

Anderson, C. J., and W. J. Mitsch, 2008. Tree basal growth response to flooding in a bottomland hardwood forest in central Ohio. Journal of the American Water Resources Association 44:1512-1520.

Bebber, D. P., S. C. Thomas, W. Cole, and D. Balsilli, 2004. Diameter increment in mature eastern white pine Pinus strobus L. following partial harvest of old-growth stands in Ontario, Canada. Trees-Structure and Function 18:29-34.

Black, B. A., and M. D. Abrams, 2005. Disturbance history and climate response in an old-growth hemlock-white pine forest, central Pennsylvania. Journal of the Torrey Botanical Society 132:103-114.

Biondi, F., and K. Waikul, 2004. DENDROCLIM2002: A $\mathrm{C}++$ program for statistical calibration of climate signals in tree-ring chronologies. Computers \& Geosciences 30:303311.

Briffa, K. R., and P. D. Jones, 1990. Basic chronology statistics and assessment. In Methods of Dendrochronology. Applications in the Environmental Sciences, edited by E. R. Cook and L. A. Kairiukstis, pp. 137-152. Kluwer Academic, Dordrecht.

Clausen, J. J., 1957. A phytosociological ordination of the conifer swamps of Wisconsin. Ecology 38:638-646.

Clinton, B. D., K. J. Elliott, and W. T. Swank, 1997. Response of planted eastern white pine (Pinus strobus L.) to mechanical release, competition, and drought in the Southern Appalachians. Southern Journal of Applied Forestry 21:19-23.

Cook, E. R., and K. Peters, 1981. The smoothing spline: A new approach to standardizing forest interior tree-ring width series for dendroclimatic studies. Tree-Ring Bulletin 41:4553.

Copenheaver, C. A., M. W. Yancey, E. Pantaleoni, and V. R. Emrick, 2007. Dendroclimatic analysis of a bottomland hardwood forest: Floodplain vs. terrace responses. Journal of the Torrey Botanical Society 134:505-511.

Dickmann, D. I., and L. A. Leefers, 2003. The Forests of Michigan. University of Michigan Press, Ann Arbor.

Dougherty, P. M., D. Whitehead, and J. M. Vose, 1994. Environmental influences of the phenology of pine. Ecological Bulletins 43:64-75.

Ford, C. R., and J. R. Brooks, 2002. Detecting forest stress and decline in response to increasing river flow in southwest Florida, U.S.A. Forest Ecology and Management 160:45-64.

Foster, T. E., and J. R. Brooks, 2001. Long-term trends in growth of Pinus palustris and Pinus elliottii along a hydrological gradient in central Florida. Canadian Journal of Forest Research 31:1661.

Fritts, H. C., 1976. Tree Rings and Climate. Academic Press, Inc., London, UK.

Gower, S. T., J. G. Isebrands, and D. W. Sheriff, 1995. Carbon allocation and accumulation in conifers. In Resource Physiology of Conifers, edited by W. K. Smith and T. M. Hinckley, pp. 217-254. Academic Press, San Diego, CA.

Graumlich, L. J., 1993. Reponse of tree growth to climatic variation in the mixed conifer and deciduous forest of the upper Great Lakes region. Canadian Journal of Forest Research 23:133-143.

Grissino-Mayer, H. D., 2001. Evaluating crossdating accuracy: A manual and tutorial for the computer program COFECHA. Tree-Ring Research 57:205-221. 
Hogg, E. H., 1997. Temporal scaling of moisture and the forestgrassland boundary in western Canada. Agricultural and Forest Meteorology 84:115-122.

Holmes, R. L., 1992. Dendrochronology Program Library, Version 1992-1. Laboratory of Tree-Ring Research, University of Arizona, Tucson,, Arizona.

Horton, K. W., and W. G. E. Brown, 1960. Ecology of White and Red Pine in the Great Lakes-St. Lawrence Forest Region. Technical Notes, Forest Research Division, Forestry Branch Canada. No. 88; 22 pp.

Jenkins, J. C., D. C. Chojnacky, L. S. Heath, and R. A. Birdsey, 2003. National-scale biomass estimators for United States tree species. Forest Science 49:12-35.

Keim, R. F., C. W. Izdepski, and J. W. Day, Jr, 2012. Growth responses of baldcypress to wastewater nutrient additions and changing hydrologic regime. Wetlands 32:95-103.

Kilgore, J. S., and F. W. Telewski, 2004. Climate-growth relationships for native and nonnative Pinaceae in Northern Michigan's Pine Barrens. Tree-Ring Research 60:3-13.

Kipfmueller, K. F., G. P. Elliott, E. R. Larson, and M. W. Salzer, 2010. An assessment of the dendroclimatic potential of three conifer species in northern Minnesota. Tree-Ring Research 66:113-126.

Kozlowski, T. T., 1997. Response of woody plants to flooding and salinity. Tree Physiology Monograph No. 1; 29 pp.

Kozlowski, T. T., P. J. Kramer, and S. G. Pallardy, 1991. The Physiological Ecology of Woody Plants. Academic Press, San Diego, CA.

Leavitt, S. W., 2007. Regional expression of the 1988 U.S. Midwest drought in seasonal $\delta^{13} \mathrm{C}$ of tree rings. Journal of Geophysical Research 112:DO6107 (14 pages).

Lussenhop, J., and R. Fogel, 1999. Seasonal changes in phosphorus content of Pinus strobus-Cenococcum geophilum ectomycorrhizae. Mycologia 91:742-746.

Mácová, M., 2008. Dendroclimatological comparison of native Pinus sylvestris and invasive Pinus strobus in different habitats in the Czech Republic. Preslia 80:277-289.

Michigan State University (MSU), 2012. Geographic Information Systems, MSU Campus Infrastructure. Available at: https://prod.gis.msu.edu/appinfrastructure (Accessed on August 13, 2012).

Orwig, D. A., and M. D. Abrams, 1999. Impacts of early selective logging on the dendroecology of an old-growth, bottomland hemlock-white pine-northern hardwood forest on the Allegheny Plateau. Journal of the Torrey Botanical Society 126:234-244.

Ostry, M. E., G. Laflamme, and S. A. Katovich, 2010. Silvicultural approaches for management of eastern white pine to minimize impacts of damaging agents. Forest Pathology 40:332-346.

Rodriguez-Gonzalez, P. M., J. C. Stella, F. Campelo, M. T. Ferreira, and A. Albuquerque, 2010. Subsidy or stress? Tree structure and growth in wetland forests along a hydrological gradient in Southern Europe. Forest Ecology and Management 259:2015-2025.

Stahle, D. W., M. K. Cleaveland, and R. S. Cerveny, 1991. Tree-ring reconstructed sunshine duration over central U.S.A. International Journal of Climatology 11:285-295.

St. George, S., D. M. Meko, and M. N. Evans, 2008. Regional tree growth and inferred summer climate in the Winnipeg River basin, Canada, since AD 1783. Quaternary Research 70:158-172.

Stokes, M. A., and T. L. Smiley, 1996. An Introduction to TreeRing Dating. The University of Arizona Press, Tucson, Arizona.

SYSTAT, 2006. SYSTAT. Version 10.2, Richmond, CA.

Telewski, F. W., 1998. The beginnings of an artificial forestry in mid-19th century Michigan: The contributions of W.J. Beal to Silviculture. The Michigan Botanist 37:35-58.

U.S. Natural Resources Conservation Service, 2012. Web Soil Survey. United States Department of Agriculture, Natural Resources Conservation Service, Soil Survey Staff. Available at: http://websoilsurvey.nrcs.usda.gov (Accessed April 17, 2012).

Wendel, G. W., and H. C. Smith, 1990. Pinus strobus L. eastern white pine. In Silvics of North America. Volume 1. Conifers, Technical coordinators R. M. Burns, Russell and B. H. Honkala, pp. 476-488. Agricultural Handbook 654. Washington, D.C., U.S. Department of Agriculture, Forest Service.

Whitney, G. G., 1990. The History and Status of the HemlockHardwood Forests of the Allegheny Plateau. Journal of Ecology 78:443-458.

Yamaguchi, D. K., 1991. A simple method for cross dating increment cores for living trees. Canadian Journal Forest Research 21:414 416 .

Received 29 August 2012; accepted 15 June 2013. 